\title{
A Study of New Trends of Welfare and Safety Arrangements for Teachers and Education Personnel
}

\author{
Kittipong Phumpuang ${ }^{1 *}$, Patcharin Buranakorn ${ }^{2}$
}

${ }^{1}$ Naresuan University, 99/9 Muang, Phitsanulok 65000, THAILAND

${ }^{2}$ Huachiew Chalermprakiet University, 18/18 Bangplee, Samutprakarn 10250, THAILAND

*Corresponding Author: kittipongp@nu.ac.th

Citation: Phumpuang, K., \& Buranakorn, P. (2019). A Study of New Trends of Welfare and Safety Arrangements for Teachers and Education Personnel. Mediterranean Journal of Social \& Behavioral Research, 3(3), 47-50. https://doi.org/10.30935/mjosbr/9594

\begin{abstract}
The purpose of this research is to study new trends and the system for the welfare and safety management of the Office of the Welfare Promotion Commission for Teachers and Education Personnel. The scope of the study is the teachers and education personnel in 5 provinces in lower northern academic area 1 covering Tak, Pitsanulok, Petchaboon, Sukhothai and Uttaradit. This study uses qualitative research methods.

The research found that with regard to new trends in welfare and safety management of the Office of the Welfare Promotion Commission for Teachers and Education Personnel, for welfare management, temporary accommodation should be provided according to the teacher's needs. Medical check-up services should cover life threatening diseases. The transportation allowance or reduction should include a variety of vehicles. Moreover, life insurance for teachers should be increased. For safety management, the interest rate on loans from the cremation fund for teachers and education personnel should be reduced and the loan application should be verified in order to meet the fund's objective. For honors and recognition, there should be scholarships for master's degrees and funding for research or academic performance. The categories and classes of the awards should be adjusted according to the teacher's accreditation. There should be a greater variety of awards for teachers.

With regard to the proposed system of welfare and safety management by the Office of the Welfare Promotion Commission for Teachers and Education Personnel, the welfare and safety management for teachers and education personnel should be arranged for their entire career as divided to three phases: before starting their career, during working, and after resignation or retirement by focusing on the care and development of teachers and educational personnel throughout their entire life, both physically and mentally. The promotion of accreditation for teachers and education personnel should be supported. In addition, the service should be changed from timely to integrated throughout the full cycle of the teacher and education personnel's life by changing from financial support to support to each person.
\end{abstract}

Keywords: welfare, safety, teachers and educational personnel, new trends

Received: 01 Jul. 2019 • Revised: 25 Sep. 2019 • Accepted: 21 Nov. 2019

\section{INTRODUCTION}

Teachers and other education personnel constitute important occupations under educational management, which is the basis of the society and the country's management. With reference to educational reform, the teaching profession is considered a noble profession. Teachers, therefore, must behave well in order to meet quality standards and must self-develop continuously. Being effective teachers and education personnel relies on several factors. One of the factors which affects a teacher's efficiency is his/her income. Teacher's income means the salary teachers earn monthly. In psychology, salary is a basic human need and meets the need of all kinds. But for Thai teachers, the problem is that when compared to other government officers, teachers are low-income government officers. They receive only a monthly salary without overtime and have no opportunity for other benefits. With the same cost of living, most teachers are rather poor and have financial problems (Kaewdaeng, 1997, p. 37-38).

Social welfare and safety for teachers and other education personnel have been provided continuously since before the establishment of the Office of the Welfare Promotion Commission for Teachers and Education Personnel in 2003 (Office of the Welfare Promotion Commission for Teachers and Education Personnel, 2009, p. 3). Thus, the researcher would like to find the answer to the question of how, with all the changes in the world today, teachers and education personnel want the Office of the Welfare Promotion Commission for Teachers and Education Personnel to manage new trends in their welfare and safety management. The researcher also wants to study the welfare and safety arrangement for teachers and education personnel: evaluation and new approach so the Office of the Welfare Promotion 
Table 1. The sample groups

\begin{tabular}{|c|c|c|c|c|c|c|c|c|c|c|c|c|}
\hline \multirow[b]{2}{*}{ Province } & \multicolumn{6}{|c|}{ Population } & \multicolumn{6}{|c|}{ Sample group } \\
\hline & OBEC & $\begin{array}{c}\text { OLA/ } \\
\text { Municipal }\end{array}$ & OPEC & VEC & NFE & Total & OBEC & $\begin{array}{c}\text { OLA/ } \\
\text { Municipal }\end{array}$ & OPEC & VEC & NFE & Total \\
\hline Pitsanulok & 8,815 & 346 & 825 & 469 & 143 & 10,598 & 10 & 2 & 1 & 1 & 1 & 15 \\
\hline Petchaboon & 7,088 & 403 & 1,189 & 318 & 172 & 9,170 & 10 & 2 & 1 & 1 & 1 & 15 \\
\hline Tak & 3,403 & 459 & 263 & 375 & 280 & 4,780 & 10 & 2 & 1 & 1 & 1 & 15 \\
\hline Sukhothai & 4,934 & 708 & 211 & 354 & 127 & 6,334 & 10 & 2 & 1 & 1 & 1 & 15 \\
\hline Uttaradit & 3,579 & 467 & 299 & 273 & 171 & 4,789 & 10 & 2 & 1 & 1 & 1 & 15 \\
\hline Total & 27,819 & 2,383 & 2,787 & 1,789 & 893 & 35,671 & 50 & 10 & 5 & 5 & 5 & 75 \\
\hline
\end{tabular}

Commission for Teachers and Education Personnel can use the findings as guidelines in improving welfare and safety arrangements for teachers and education personnel in accordance with the social changes taking place at the present time.

\section{OBJECTIVE}

1. To study the new trends of welfare and safety arrangements by Office of the Welfare Promotion Commission for Teachers and Education Personnel

2. To recommend trends of welfare and safety arrangements by Office of the Welfare Promotion Commission for Teachers and Education Personnel

\section{RESEARCH METHODOLOGY}

This research is qualitative research employing the following:

1. Structured in-depth interviews to find the new trends of welfare and safety arrangements for teachers and educational personnel in lower northern academic area 1 by identifying the sample group as follows:

Sample group of structured in-depth interviews includes teachers and educational personnel who are members of OTEP in 5 provinces in lower northern academic area 1: Pitsanulok, Petchaboon, Tak, Sukhothai, and Utttaradit. For the second objective, the sample group was identified from agency representatives in each province. The sample group is comprised of 75 people in total using stratified random sampling by province and agency. The sample group in each province and agency are listed in Table 1.

2. Group conversation: for recommendations regarding welfare and safety arrangements by the Office of the Welfare Promotion Commission for Teachers and Education Personnel, the following sample group was used:

a. Sample group of 5 experts selected from experts in fields related to welfare and safety management, such as university lecturers, lawyers, officers in OTEP, private organizations, and the Office of Education.

b. Sample group of 5 teachers and educational personnel: 1 person from each province selected by the Office of Education in the 5 provinces from teachers and education personnel who are interested and regularly study the welfare and safety arrangements for teachers and education personnel.

\section{INSTRUMENTS}

There were 2 types of instruments used in this research as follows:

1. Structured in-depth interviews to find new trends of welfare and safety arrangements of the Office of the Welfare Promotion Commission for Teachers and Education Personnel.

2. Five questions or talking points were used in the group conversations among teachers and education personnel and experts in order to brainstorm about new trends of welfare and safety arrangements of the Office of the Welfare Promotion Commission for Teachers and Education Personnel.

\section{RESEARCH FINDINGS}

Study of new trends of welfare and safety arrangements by the Office of the Welfare Promotion Commission for Teachers and Education Personnel

\section{Teachers'opinions about new trends about knowledge development}

Teachers and education personnel from 5 provinces commented that OTEP should provide scholarships for teachers and education personnel, such as short-term English study scholarships, domestic and international training, or visit and postgraduate scholarships, etc. This would meet the teachers' needs because these provide opportunities for teachers to enhance their knowledge so that they are able to improve their teaching and upgrade their level of education. Teachers would have a wide range of choices in career development. Short term English study meets their need as Thailand is entering AEC. Postgraduate scholarships also accord with teachers' needs since the scholarship for postgraduate study is rarely offered and its criteria do not meet their requirement such as study period. The criteria should be set to cover all requirements as to period of time and type which should cover both primary and secondary school teachers. Moreover, in postgraduate study, there is research on teaching which teachers would like to learn in order to apply in their class and improve the quality of their teaching. In addition, if the scholarship can be extended to the doctoral level, this will also meet teachers' needs.

\section{New trends in welfare and safety arrangement}

\section{Welfare}

- Temporary accommodation should be provided according to the teacher's needs. The number of rooms in the teacher's dormitory should be increased and its location should not only be in Bangkok but also in larger provinces of each area. 
- Medical check-up services should be extended to cover more and should cover life threatening diseases without any charge, such as heart disease, colon cancer, breast cancer, cervical cancer, AIDS, etc.

- Teachers rarely use the discount for the train because it is not convenient. The discount should be extended to other modes of transportation, such as airplane, bus, van, etc.

- Group insurance should be added for teachers so that they can go to private hospitals.

- Low interest installments for electrical appliances should be available.

\section{Safety}

- Teachers seldom know about the safety service which is provided by OTEP. So, public relations should be increased to spread the information, and teachers can learn more about welfare and safety arranged by OTEP.

- Interest rates on loans from the cremation fund should be reduced.

- The loan application should be verified to meet the fund's objective, and the borrowers should be monitored to ensure that they use the money according to the loan's objective.

- There should be a fund in case their relative is sick because nonformal and informal education teachers earn very little.

\section{Recognition}

- Postgraduate scholarships should be provided.

- There should be a research fund for academic work.

- Academic training related to promotion should be promoted.

- Categories and awards each year should be adjusted according to their promotion.

\section{Benefits of new trends to teacher and education personnel}

The new trends above are beneficial to teachers as follows:

- Medical check-up services cover life threatening diseases. If such diseases are found, teachers will be treated promptly after finding the disease. If not found, they will be in good mental health. For elder teachers who are competent and have long time experience but are not healthy, their medical service is more important than at other ages.

- A discount for transportation fees is good for traveling to go for training and seminars for self-development.

- Reducing interest rates: teachers are able to reduce their debt faster.

- More variety of awards encourages teachers to grow in their career and is beneficial to their promotion.

- Scholarships are beneficial to their learning development and their self-development in order to improve their efficiency and encourage them to continue self-development. Scholarships reduce the burden in self-development. Sometimes, teachers would like to develop themselves, but they have a problem with expenses, such as course fee, transportation fee, accommodation fee, etc. Some teachers give up their own development.

- Award arrangements encourage teachers to attain a higher academic standing which can help them to reduce debt, costs, and increase their mental support. This helps to increase the teacher's welfare.
- Group life insurance helps teachers save time. Teachers are able to go to private hospitals after teaching hours.

- This is beneficial to all teachers, so they do not become a burden for society and their children. They are able to stand securely and proudly.

- This is beneficial to morale and supports the teachers' work and their life. Their life becomes better and happy.

In conclusion, the new trends as presented are beneficial to their morale, and they support their work and their life. The new trends above are good for teachers in every aspect. When teachers are well treated, the quality of teaching is improved and good for students.

Recommendations regarding the welfare and safety arrangement by OTEP

The welfare and safety arrangement for teachers and educational personnel should be arranged for their entire career which is divided into 3 periods as follows:

\section{Before becoming a teacher and education personnel}

This includes persons who passed the test and are waiting to join or who are just starting their career, during the first 3 years.

\section{Welfare and safety management}

Educating teachers and education personnel about financial planning, welfare, and safety services offered by OTEP.

\section{Process of welfare and safety arrangement}

1) Orientation for new teachers and education personnel related to saving money and salary management from day 1 of their career by dividing their salary in 4 funds: $65 \%$ for spending, $5 \%$ for parents, $15 \%$ for buying a home, and $15 \%$ for a provident fund. When elderly, these funds can be reallocated according to their needs but should be kept in these 4 main funds.

2) Providing training with regards to welfare and safety arranged by OTEP in order that they use the service since the start of work.

\section{Benefits to the life of teachers and education personnel}

1) Teachers and education personnel well organize their finances before becoming teachers.

2) Teachers know and understand their welfare and safety arranged by OTEP so that they have financial planning together with benefits from projects arranged by OTEP.

While working as teachers and education personnel: this means the entire life of teachers and education personnel.

\section{Welfare and safety arrangements}

1) Supervise and develop their entire life, both physically and mentally.

2) Support their promotion for academic standing

3) Change from one-time service to integrated continuing and full cycle service for their entire life by changing from financial support to support to individual persons

\section{Process of welfare and safety arrangement}

1) Providing more medical services both physical and psychological. Adding medical check-up services for life threatening diseases beyond basics, such as breast cancer, cervical cancer, prostate cancer, blood disease, AIDS, etc. 
2) Raising funds for self-development to enhance their academic standing. This fund can either be a non-condition scholarship or an onloan scholarship for use during training and doing research in order to get promoted or be a trainer who develops teachers in enhancing their academic standing.

3) Arranging academic seminars or exhibitions related to services of OTEP for nationwide teachers by rotating to each area yearly and regularly evaluating the service.

\section{Benefits to teachers and education personnel}

1) Benefits to their physical and psychological life-long health

2) Benefits to their career progress

3) Benefits to public relation of the service managed by OTEP and to use the service of teachers and education personnel

\section{Post-teacher and education personnel career:}

This means persons who teach until 60 years of age and retire and includes teachers and education personnel who work at least 20 years and resign.

\section{Welfare and safety arrangements}

1) Offer other career training before retirement or resignation

2) Offer medical service after retirement or resignation

3) Offer activities to promote health awareness and self-awareness for teachers and education personnel who retire or resign

\section{Process of welfare and safety arrangements}

1) Survey their wish to train and type of career in which they are interested 3-5 years before retirement or resignation

2) Medical institutes under OTEP organize the medical-check project for teachers and education personnel after retirement or resignation regularly 3-4 times a year and if life threatening diseases have been found, they should be transferred to a public hospital.

3) Organizing health activities or self-esteem workshops for teachers who retire or resign.

\section{Benefits to the life of teachers and educational personnel}

1) Teachers and education personnel have professional skills for alternative work after ending their career.

2) Teachers receive health care from personnel in expert medical institutes.

3) Teachers and education personnel know and understand how to take care of their health correctly and have self-esteem even though they do not work as teachers.

In conclusion, for the recommendations regarding the welfare and safety arrangements by OTEP, the welfare and safety for teachers and education personnel should be arranged for their entire career life by dividing into 3 phrases: before entering the career, during working, and after finishing the career by focusing on care and development for their entire life, both physical and mental. The promotion of accreditation for teachers and education personnel should be supported. In addition, the service should be changed from timely to integrated continuing and full cycle for the entire life of teachers and education personnel by changing from financial support to support to individual persons.

\section{DISCUSSION OF THE FINDINGS}

Welfare and safety arranged by the Office of the Welfare Promotion Commission for Teachers and Education Personnel should be provided to teachers and education personnel for their entire career life by dividing into 3 periods: before entering the career, during working, and after finishing the career by focusing on care and development for their entire life both physical and mental. The promotion of accreditation for teachers and education personnel should be supported. In addition, the service should be changed from timely to integrated continuing and full cycle for the entire life of teachers and education personnel by changing from financial support to support to individual persons, emphasizing integrated services for their entire life in order that teachers become personnel of the country who are both physically and mentally sound, so they are able to use their integrity to develop other learners. This result is in accordance with the result of Turner et al. (1986, p. 5-11) who found that strategic policy and salary motivation are related and directly influence a student's learning progress. Consequently, if a teacher has good welfare, efficiency in teaching will be improved and results in better learning development as well.

\section{SUGGESTIONS}

1. The research scope can be extended to all areas in order for OTEP to apply the result to improve and develop their welfare management to meet the needs of teachers nationwide with more efficiency.

2. The target group can be extended to Border Petrol Police Schools in wilderness areas where teacher's needs may be different from ones in urban areas so that OTEP is able to apply the result to improve and develop their welfare management in accordance with teachers needs in wilderness areas.

3. Research can be extended to a comparative study of welfare and safety arrangements for teachers and education personnel among ASEAN countries. OTEP can then apply the result to improve and develop our welfare to be a peer with other ASEAN countries.

\section{REFERENCES}

Kaewdaeng, R. (1997). National Teachers: Resolution for teacher problem in the future. Matichon Sudsapda, 18.

Office of the Welfare Promotion Commission for Teachers and Educational Personnel (2009). Role and mission of Office of the Welfare Promotion Commission for Teachers and Educational Personnel. Bangkok: Office of the Welfare Promotion Commission for Teachers and Educational Personnel.

Turner, R., Camilli, G., Kroc, R., \& Hoover, J. (1986). Policy Strategies, Teacher Salary Incentive and Student Achievement: An Explanatory Model. Educational Researcher, 15(3), 5-11. https://doi.org/10.3102/0013189X015003005 